\title{
Controlling Growth of Tabletop Christmas Trees with Plant Growth Retardants
}

\author{
M.W. Duck, B.M. Cregg ${ }^{1}$, \\ R.T. Fernandez, R.D. Heins, \\ and F.F. Cardoso
}

Additional index words. Picea, Abies, Thuja, Chamaecyparis, Psendotsuga, paclobutrazol, daminozide, uniconazole, ancymidol, chlormequat, ethrel

\begin{abstract}
Summary. Tabletop Christmas tree growers whose greenhouse-grown conifers have undesirable shoot growth may alleviate this problem by applying plant growth retardants (PGRs). Some of the most common PGRs in the horticulture industry were evaluated to determine their effectiveness in controlling plant height: ancymidol at $100 \mu \mathrm{L} \cdot \mathrm{L}^{-1}(\mathrm{ppm})$, daminozide at $5000 \mu \mathrm{L} \cdot \mathrm{L}^{-1}$, paclobutrazol at 60 $\mu \mathrm{L} \cdot \mathrm{L}^{-1}$, chlormequat at $1500 \mu \mathrm{L} \cdot \mathrm{L}^{-1}$, uniconazole at $15 \mu \mathrm{L} \cdot \mathrm{L}^{-1}$, and ethephon at $500 \mu \mathrm{L} \cdot \mathrm{L}^{-1}$ compared to a nontreated control. The following conifer species were used: colorado blue spruce (Picea pungens), black hills spruce ( $P$. glauca var. densata), serbian spruce ( $P$. omorika), noble fir (Abies procera), grand fir (A.grandis), fraser fir (A. fraseri), concolor fir (A. concolor), arborvitae (Thuja occidentalis), port orford cedar (Chamaecyparis lawsoniana), and douglas-fir (Pseudotsuga menziesii). Chlormequat was the only PGR that caused phytotoxicity and damage to the foliage was minimal. Noble fir, douglas-fir, colorado blue spruce, and arborvitae were unaffected by any PGR treatment. Daminozide reduced growth of port orford cedar and concolor fir; uniconazole reduced growth of black hills spruce and serbian spruce; paclobutrazol reduced growth of fraser fir; and ethephon reduced growth of grand fir.
\end{abstract}

$\longrightarrow$

The use of plant growth retardants is common practice in the horticulture industry (Schott and Walter, 1991) for promoting

Department of Horticulture, Michigan State University, East Lansing, MI 48824

${ }^{1}$ To whom reprint requests should be addressed; e-mail address: cregg@msu.edu 
more uniform plant development, controlling flower and fruit production, and most importantly, reducing plant growth (Larson, 1992). In many plants, PGRs reduce shoot length without causing detrimental effects, such as phytotoxicity or undesirable development (Grossmann, 1990; Rademacher, 1991). Plant growth retardants reduce both the rate of cell division and cell elongation (Rademacher, 1991). These effects are related to inhibition of the gibberellins (GAs), auxins, or both, which are important hormones responsible for shoot elongation.

Considerable research has been performed on PGRs to determine their effectiveness in controlling growth of conifer species (Asher, 1963; Dunberg and Eliasson, 1972; Groninger and Seiler, 1997; Hare, 1982; Keever and West, 1992; Kuo and Pharis, 1975; Ruddat and Pharis, 1966; Ruter, 1994; Van den Driessche, 1989, 1996; Weston et al., 1980). In general, the emphasis of these studies has been to determine the effectiveness of PGRs to reduce transplanting stress or as a means of height control under utility rights-of-way. Growers who produce coniferous tabletop Christmas trees in a greenhouse environment may benefit financially by using PGRs. Most conifers undergo a rapid growth phase after seedlings become established (Landis et al., 1992; Young and Hanover, 1976). PGRs can limit excessive elongation under optimal conditions (Barrett, 1992) to produce uniform, aesthetically pleasing tabletop Christmas tree plants.

Currently, species used for tabletop Christmas trees, such as italian stone pine (Pinuspinea), are not hardy in the northern U.S. and cannot be planted outdoors after the Christmas season. This study was conducted as part of an overall program to develop a production system for conifer and greenhouse growers to produce an affordable and marketable live tabletop Christmas tree, hardy in the upper midwestern U.S., by evaluating effectiveness of PGRs in controlling seedling height and development.

\section{Materials and methods}

Plant material and Culture. The following seedlings, grown in $100 \mathrm{~cm}^{3}$ $\left(6.1\right.$ inch $^{3}$ ) Jiffy-7 peat pellets (Jiffy Products of America, Batavia, Ill.), were received from a local nursery (Vans Pines Nursery, West Olive, Mich.) in Nov. 1999 and given 10 weeks of chilling at $3{ }^{\circ} \mathrm{C}\left(37.4{ }^{\circ} \mathrm{F}\right)$ : colorado blue spruce, black hills spruce, serbian spruce, noble fir, grand fir, fraser fir, concolor fir, arborvitae, port orford cedar, and douglas-fir. At the beginning of the trial, seedlings ranged in size from 11 to $61 \mathrm{~cm}(4.3$ to 24.0 inches). The seedlings were planted on 27 Jan. 2000 in $13 \times 13-\mathrm{cm}(5.1$ inches) square pots $\left[1100 \mathrm{~cm}^{3}(67.1\right.$ inch $\left.^{3}\right)$ ] using a commercial medium (Strong-Lite High Porosity Mix, Pine Bluff, Ark.) composed of pine bark, fibrous Canadian sphagnum peat, horticultural vermiculite, and screened course perlite, along with a wetting agent and a starter fertilizer charge. The greenhouse temperature was set at $20^{\circ} \mathrm{C}\left(68.0^{\circ} \mathrm{F}\right)$ and 16 -h day-extension photoperiod using high-pressure sodium lamps. The seedlings were irrigated with a nutrient solution of well water (electrical conductivity of 0.65 $\mathrm{mS} \cdot \mathrm{cm}^{-1}$ and $105,35,23 \mathrm{mg} \cdot \mathrm{L}^{-1}(\mathrm{ppm})$ calcium $(\mathrm{Ca})$, magnesium $(\mathrm{Mg})$, and sulfur $(S)$, respectively, acidified with sulfuric acid $\left(\mathrm{H}_{2} \mathrm{SO}_{4}\right)$ to a titratable alkalinity of calcium sulfate $\left(\mathrm{CaSO}_{2}\right)$ at $130 \mathrm{mg} \cdot \mathrm{L}^{-1}$ and water-soluble fertilizer providing $125 \mathrm{mg} \cdot \mathrm{L}^{-1}$ nitrogen $(\mathrm{N}), 12 \mathrm{mg} \cdot \mathrm{L}^{-1}$ phosphorus $(\mathrm{P}), 125$ $\mathrm{mg} \cdot \mathrm{L}^{-1}$ potassium $(\mathrm{K}), 13 \mathrm{mg} \cdot \mathrm{L}^{-1} \mathrm{Ca}$, $1.0 \mathrm{mg} \cdot \mathrm{L}^{-1}$ iron $(\mathrm{Fe}), 0.5 \mathrm{mg} \cdot \mathrm{L}^{-1} \mathrm{man}^{-}$ ganese $(\mathrm{Mn}), 0.5 \mathrm{mg} \cdot \mathrm{L}^{-1} \mathrm{zinc}(\mathrm{Zn}), 1.0$ $\mathrm{mg} \cdot \mathrm{L}^{-1} \operatorname{copper}(\mathrm{Cu}), 0.2 \mathrm{mg} \cdot \mathrm{L}^{-1}$ boron (B), and $0.1 \mathrm{mg} \cdot \mathrm{L}^{-1}$ molybdenum (Mo) (MSU Special, Greencare Fertilizers, Chicago).

Treatments. Seedlings were arranged in a completely randomized design using five plants per species in each of the following treatments: 1) ancymidol (A-rest; SePRO Corp., Carmel, Ind.) at $100 \mu \mathrm{L} \cdot \mathrm{L}^{-1}$; 2) daminozide (B-nine; Uniroyal Chemical, Middlebury, Conn.) at $5000 \mu \mathrm{L} \cdot \mathrm{L}^{-1}$; $3)$ paclobutrazol (Bonzi; Syngenta, Wilmington, Del.) at $\left.60 \mu \mathrm{L} \cdot \mathrm{L}^{-1} ; 4\right)$ chlormequat (Cycocel; Olympic Horticultural Products Co., Mainland, Pa.) at $\left.1500 \mu \mathrm{L} \cdot \mathrm{L}^{-1} ; 5\right)$ uniconazole (Sumagic; Valent U.S.A. Corp., Walnut Creek, Calif.) at $\left.15 \mu \mathrm{L} \cdot \mathrm{L}^{-1} ; 6\right)$ ethephon (Florel; Monterey Lawn and Garden Products, Fresno, Calif.) at $500 \mu \mathrm{L} \cdot \mathrm{L}^{-1}$; and 7 ) a nontreated control. These rates were determined according to protocols of prior PGR work performed by the Michigan State University floriculture group (Niu et al., 2002). Beginning 15 May 2000, plant growth retardants along with a wetting agent (Capsil; Aquatrols Corp. of America, Cherry Hill, N.J.) were applied as a spray to the seedling foliage until runoff. Sprays were applied at 2-week intervals throughout a 10-week period for a total of five applications.

Data Collection and analysis. Plant height was recorded at the beginning of the experiment, and the day before each PGR application. Final height was determined 2 weeks after the last chemical application. From the height data, mean relative growth rate (RGR) was determined by an exponential height growth model (Hunt, 1982; Wang et al., 2000):

$\mathrm{RGR}=[\ln ($ final height $)-\ln ($ initial height)]/time in weeks

Relative growth rate data were transformed by using the square root (SQRT) function (SAS/PC software; SAS Institute, Cary, N.C.) to achieve normal distribution on the residual terms. Main effects of PGR treatment and species and PGR $\times$ species interaction effect of relative growth rate were tested by the SAS PROC MIXED procedure (SAS Institute) .

\section{Results and discussion}

Species, PGR, and species $\times$ PGR interaction effects on mean relative growth rate of seedlings were significant $(P<0.05$, Table 1$)$. Plant height was decreased by at least one PGR treatment for six of the 10 species we tested (Figs. 1, 2, and 3). However, the RGR of douglas-fir, noble fir, colorado blue spruce, and arborvitae was not affected by PGR treatments (Table $2)$. Chlormequat, daminozide, and ethephon caused minimal phytotoxicity, which occurred only with true fir species (Abies). Because of interactions between species and PGR, it is difficult to make generalized recommendations for the overall experiment; therefore, results are presented below by PGR.

ETHePHon. Ethephon reduced growth of fraser fir, concolor fir, and grand fir (Fig. 1) and black hills spruce

Table 1. Analysis of variance for mean relative growth rate of 10 tabletop conifer species treated with seven plant growth retardant (PGR) treatments.

\begin{tabular}{|c|c|c|}
\hline Effect & df & F value \\
\hline PGR & 6 & ${ }^{\star *} 3.27$ \\
\hline Species & 9 & ${ }^{* * *} 177.84$ \\
\hline PGR $\times$ Species & 54 & ${ }^{* *} 2.38$ \\
\hline
\end{tabular}




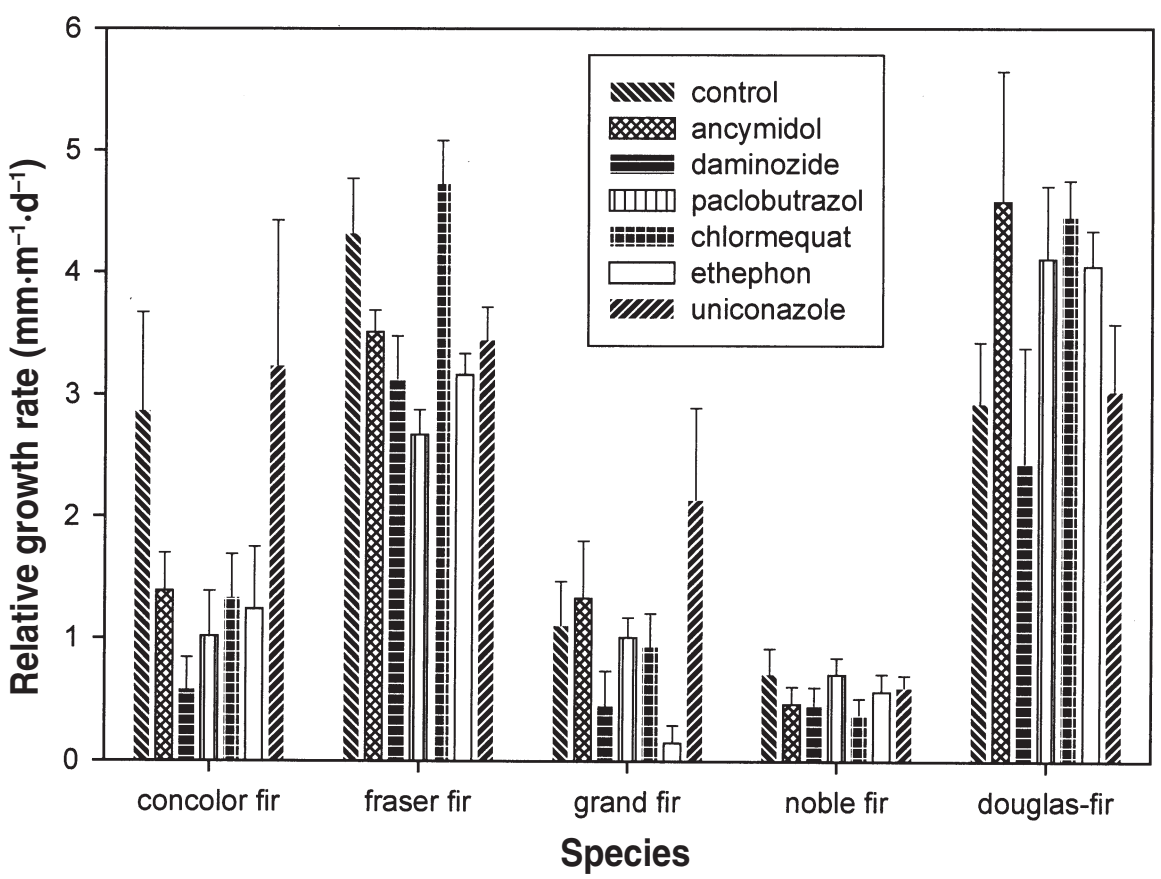

Fig. 1. Effects of plant growth retardant applications on mean relative growth rates of concolor fir, Fraser fir, grand fir, noble fir, and douglas-fir seedlings. Error bars represent $\mathrm{SE}$ of the mean. $1 \mathrm{~mm} \cdot \mathrm{m}^{-1} \cdot \mathrm{d}^{-1}=0.12 \mathrm{inch} / \mathrm{ft}$ per day.

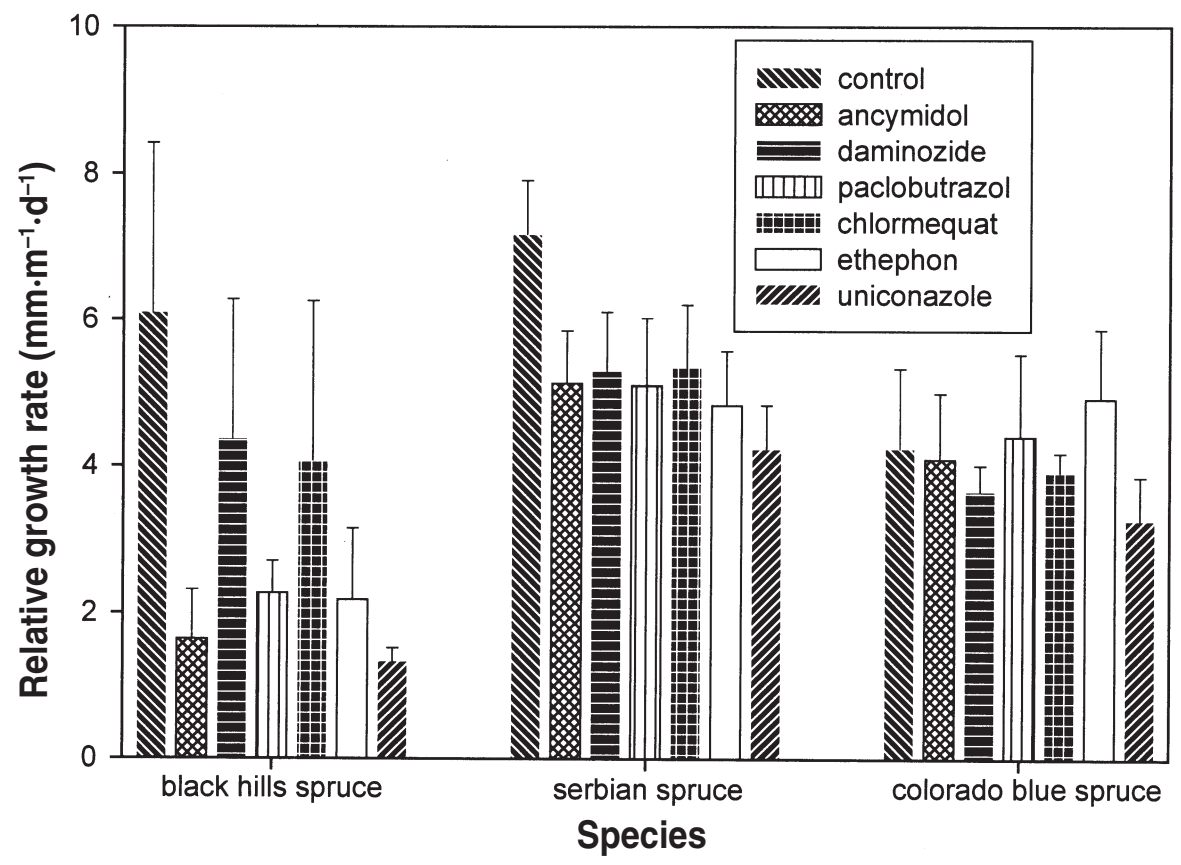

Fig. 2. Effects of plant growth retardant applications on mean relative growth rates of black hills spruce, serbian spruce, and colorado blue spruce seedlings. Error bars represent $\mathrm{SE}$ of the mean. $1 \mathrm{~mm} \cdot \mathrm{m}^{-1} \cdot \mathrm{d}^{-1}=0.12 \mathrm{inch} / \mathrm{ft}$ per day.

and serbian spruce (Fig. 2) species (Pinaceae); however, neither port orford cedar nor arborvitae (Cupressaceae) species was affected (Fig. 3). Research performed to determine effects of ethephon applications on plant growth has mainly been directed toward floriculture and ornamental crops, giving little insight into responses observed with coniferous species. Azaleas (Rhododendron spp.) and geraniums (Pelargonium spp.) treated with ethephon responded with an increase in lateral branching, resulting in shorter, fuller specimens (Neumann, 1988). Hayashi et al. (2001) observed increased branching in herbaceous perennials they treated with ethephon, although height also increased. However, lodgepole pine (Pinus contorta var. latifolia) and white spruce (Picea glauca) had reduced shoot growth when treated with ethephon (Weston et al., 1980). Unlike Pinaceae species we tested, slash pine (P. elliotti var. elliottii) and loblolly pine (P. taeda) treated with ethephon resulted in an increase in height (Hare, 1982).

Concolor fir expressed minor phytotoxic symptoms on newly expanded foliage. Foliar tissue developed light-pink to purple discolorations after the third application. Similar discoloration has been observed in balsam fir (Abies balsamea) after applications of benzyladenine (BA) (Little, 1985). Temporary symptoms were observed when BA was applied too soon to new growth.

DAminozide. Daminozide was effective in controlling height of fraser fir and concolor fir (Fig. 1), serbian spruce (Fig. 2), and port orford cedar (Fig. 3). All other species tested were not affected. Similar to ethephon, little research has been performed on conifer species to determine efficacy of daminozide applications. Hare (1982) observed that growth of slash and loblolly pine was reduced compared with that of the control. Increased branching of redwood (Sequoia sempervirens) seedlings, caused by lateral buds escaping apical dominance, occurred after daminozide was applied to seedling foliage (Ruddat and Pharis, 1966). Norway spruce (Picea abies) treated with soil drench applications of daminozide experienced reduced shoot and root growth (Dunberg and Eliasson, 1972). They detected phytotoxicity in roots and subsequently in the shoots at high concentrations (300 $\mathrm{mg} \cdot \mathrm{L}^{-1}$ ), indicating daminozide is more beneficial when applied to seedling foliage.

Chlormequat. Although chlormequat effectively controls height of many plant species (Barrett, 1992; Larson, 1992), concolor fir (Fig. 1) and serbian spruce (Fig. 2) were the only species we tested that experienced height reduction, which could be explained by the growth habit of these seedlings. Most seedlings of conifer species, including those we tested, experience a rapid growth phase (Landis et al., 1992; Young and Hanover, 1976). Cathey (1964) found that 


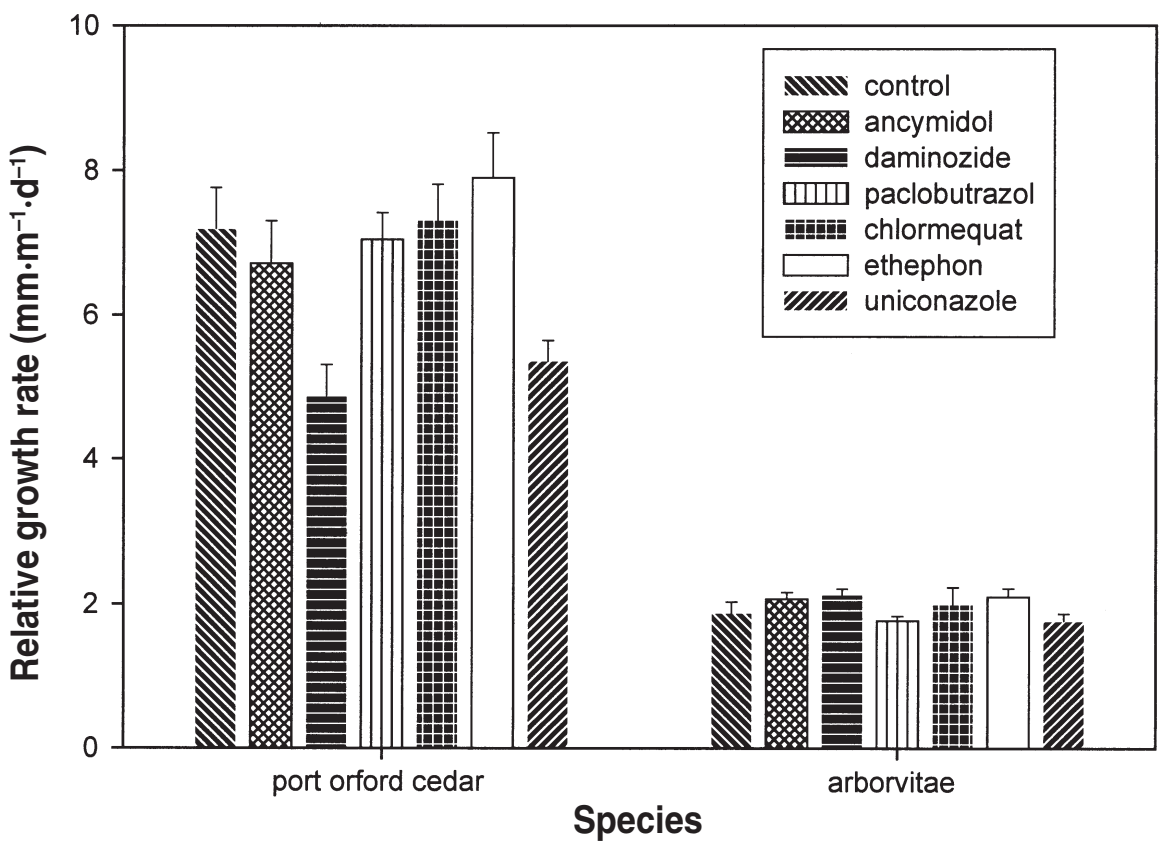

Fig. 3. Effects of plant growth retardant applications on mean relative growth rates of port orford cedar and arborvitae seedlings. Error bars represent SE of the mean. $1 \mathrm{~mm} \cdot \mathrm{m}^{-1} \cdot \mathrm{d}^{-1}=0.12 \mathrm{inch} / \mathrm{ft}$ per day.

Table 2. Mean initial and final heights, differences between control and most effective plant growth retardant (PGR) treatments, and PGRs that caused phytotoxicity in 10 species of tabletop Christmas trees.

\begin{tabular}{lcccl}
\hline & $\begin{array}{c}\text { Mean } \\
\text { initial ht of } \\
\text { the control } \\
(\mathbf{c m})^{\mathrm{z}}\end{array}$ & $\begin{array}{c}\text { Mean } \\
\text { final ht of } \\
\text { the control } \\
(\mathbf{c m})\end{array}$ & $\begin{array}{c}\text { Difference between } \\
\text { control and } \\
\text { most effective } \\
\text { PGR treatment (cm) }\end{array}$ & $\begin{array}{c}\text { PGR causing } \\
\text { phytotoxicity }\end{array}$ \\
\hline Concolor fir & 20.8 & 25.7 & 4.1 (Daminozide) & Ethephon \\
Fraser fir & 15.7 & 21.4 & 2.4 (Paclobutrazol) & Chlormequat \\
Grand fir & 15.1 & 16.4 & 1.1 (Ethephon) & Chlormequat \\
Noble fir & 24.3 & 25.6 & 0.7 (Chlormequat) ${ }^{\mathrm{Ns}}$ & Chlormequat \\
Douglas-fir & 26.6 & 32.8 & 0.7 (Daminozide) ${ }^{\mathrm{Ns}}$ & \\
Black hills spruce & 25.5 & 40.4 & 12.5 (Uniconazole) & \\
Serbian spruce & 23.4 & 39.4 & 7.4 (Uniconazole) & \\
Colorado blue spruce & 21.4 & 29.3 & 1.5 (Uniconazole) & \\
Port orford cedar & 33.8 & 56.6 & 10.7 (Daminozide) & \\
Arborvitae & 41.8 & 47.8 & 0.3 (Paclobutrazol) & \\
\hline
\end{tabular}

${ }^{\mathrm{z}} 1 \mathrm{~cm}=0.39$ inches

${ }^{\text {ss }}$ Not significantly different from the control.

height control in more vigorous plants was obtained only after high rates of PGRs were applied. Also, plants grown under long photoperiods and treated with chlormequat were not affected. Asher (1963) observed reductions in growth of slash pine given foliar treatments of chlormequat at 2000 to $16,000 \mu \mathrm{L} \cdot \mathrm{L}^{-1}$. In our trial, chlormequat was applied at $1500 \mu \mathrm{L} \cdot \mathrm{L}^{-1}$ and seedlings were grown under a 16-h photoperiod. Long photoperiod, along with such a low application rate, may explain why we detected reduced growth with so few species.

Yellowing of foliage tips was com- mon on grand fir, fraser fir, and noble fir, mainly on the most recent flushes of growth. These symptoms were not observed on the other species tested, nor were they observed in the control. Previous researchers reported that soil drench applications were more beneficial because of the high incidence of applications. Foliar damage and even death occurred in slash pine seedlings treated with high rates of chlormequat $\left(16,000 \mu \mathrm{L} \cdot \mathrm{L}^{-1}\right)$ (Asher, 1963). Phytotoxic symptoms on most plant species generally appear as chlorotic spotting within 3 to $5 \mathrm{~d}$ of foliar application phytotoxicity after foliar chlormequat and appeared mainly in foliage that was expanding at application (Barrett, 1992). For chlormequat to be considered as a means for controlling height of conifer species, higher, more effective rates must be determined, and treatments should be soil-applied to avoid foliar damage.

Ancymidol. Concolor fir and fraser fir (Fig. 1) and black hills spruce and serbian spruce (Fig. 2) had decreased shoot growth, but Cupressaceae species were not affected (Fig. 3). Although we applied ancymidol to seedling foliage, this chemical has been less effective when used as a soil drench on plants potted in media with high percentages of pine bark humus, which is occasionally used for containerized conifer crops (Larson, 1992). Similar work has been performed on Pinaceae species, successfully reducing shoot growth. Both lodgepole pine and white spruce seedlings had reduced shoot growth after soil drench applications of ancymidol (Weston et al., 1980). Reduced shoot growth occurred on 4- or 5-year-old monterey pines $(P$. radiata) treated with foliar applications of ancymidol (Hield et al., 1977). Compared with that of the control, shoot growth was reduced (by 69\%) for up to 6 months.

Uniconazole. Applications of uniconazole effectively controlled height of Pinaceae and Cupressaceae species. Shoot growth of fraser fir (Fig. 1), black hills spruce and serbian spruce (Fig. 2), and port orford cedar (Fig. 3) was reduced. Unlike the PGRs discussed earlier, much work has been performed to determine uniconazole's effects on conifers. Fraser fir terminal shoot length was reduced by $22 \%$ to $45 \%$ after uniconazole was applied to seedling foliage (Hinesley, 1998). Uniconazole applied as a soil drench to 3 -year-old loblolly pine reduced elongation by $55 \%$, as determined 3 months after treatments ended (Barnes and Kelley, 1992). Keever and West (1992) applied uniconazole as a soil drench to containerized leyland cypress (x Cupressocyparis leylandii). Growth was reduced as much as $48 \%$.

Many researchers have also determined that uniconazole is more effective as a soil drench (Barnes and Kelley, 1992; Hinesley, 1998; Keever and West, 1992; Warren, 1990; Warren et al., 1991). Unlike the PGRs discussed above, uniconazole readily moves through xylem tissue rather than 
phloem tissue (Barrett, 1992). Xylem tissue is responsible for transporting material from roots upward into the growing tips of the plant. Therefore, soil drenches are more effective in distributing the PGR throughout the plant. Considering the success other researchers have experienced from uniconazole applications on many plant species, applying uniconazole to plant foliage instead of soil may help explain why we did not observe more pronounced effects on many of the species that we tested.

Paclobutrazol. Paclobutrazol reduced shoot growth of concolor fir and fraser fir (Fig. 1) and black hills spruce and serbian spruce (Fig. 2); however, neither Cupressaceae species responded to these applications (Fig. 3). Groninger and Seiler (1997) and Wheeler (1987) observed similar responses in Pinaceae species. Ruter (1994) observed decreased shoot elongation in juniper (Juniperus spp.) that received soil-applied paclobutrazol. Paclobutrazol applied as a soil drench to douglas-fir seedlings resulted in reductions of shoot dry weight and shoot growth (Van den Driessche, 1989; Wheeler, 1987). Paclobutrazol as a soil drench was more effective than as a foliar spray in controlling shoot growth. Although we observed reductions in shoot growth with some of the species, effects could probably be detected with more of the species we tested if paclobutrazol were applied as a soil drench.

Conclusion. The use of PGRs as a means for controlling growth of conifers could prove beneficial for tabletop Christmas tree producers. As we observed in this trial and also from work performed by other researchers, PGRs can be effectively used on conifer species for reducing plant height and increasing lateral branching. Of the six PGRs we tested, daminozide and uniconazole were most beneficial because of their effectiveness in controlling growth with the widest variety of species (Pinaceae and Cupressaceae species). Chlormequat, uniconazole, and paclobutrazol were also effective PGRs but need further testing to determine more effective rates as soil-applied treatments and to determine whether soil drenching can decrease phytotoxicity observed with chlormequat. Treatments of ethephon and ancymidol also effectively controlled seedling height, but only for Pinaceae species.

\section{Literature cited}

Asher, W.C. 1963. Effects of 2-chloroethyltrimethylammonium chloride and 2,4-dichlorobenzyltributyl phosphonium chloride on growth and transpiration of slash pine. Nature 200:912.

Barnes, A.D. and W.D. Kelley. 1992. Effects of a triazole, uniconazole, on shoot elongation and root growth in loblolly pine. Can. J. For. Res. 22:1-4

Barrett, J.E. 1992. Mechanisms of action, p. 12-18. In: H.K. Tayama, R.A. Larson, P.A. Hammer and Teresa J. Roll. Tips on the use of chemical growth regulators on floriculture crops. Ohio Florists' Assn., Columbus.

Burg, S.P. and E.A. Burg. 1967. Inhibition of polar auxin transport by ethylene. Plant Physiol. 42:1224-1228

Cathey, H.M. 1964. The physiology of growth retarding chemicals. Annu. Rev. Plant Physiol. 15:271-302.

Dunberg, A. and L. Eliasson. 1972. Effects of growth retardants on norway spruce (Picea abies). Physiol. Plant. 26:302-305.

Groninger, J.W. and J.R. Seiler. 1997. Soil texture and moisture availability impacts on the efficacy of soil-applied paclobutrazol. J. Arboricult. 23(3):89-92.

Grossmann, K. 1990. Plant growth retardants as tools in physiological research. Physiol. Plant. 78:640-648.

Hare, R.C. 1982. Effect of nine growth retardants applied to loblolly and slash pine. Can. J. For. Res. 12:112-114.

Hayashi, T., R.D. Heins, A.C. Cameron, and W.H. Carlson. 2001. Ethephon influences flowering, height, and branching of several herbaceous perennials. Scientia Hort. 91:305-323.

Hield, H., R.M. Sachs, and S. Hemstreet. 1977. Growth reduction comparisons of 9 plant regulators applied to Pinus radiata. Proc. Plant Growth Regulators Working Grp., Hot Spring, Ark.

Hinesley, L.E. 1998. Effect of uniconazole on shoot growth and budset of containerized fraser fir. HortScience 33(1):82-84.

Hunt, R. 1982. Plant growth curves: The functional approach to plant growth analysis. Edward Arnold, London.

Keever, G.J. and M.S. West. 1992. Response of established landscape plants to uniconazole. HortTechnology:465-468.

Kuo, C.G. and R.P. Pharis 1975. Effects of AMO-1618 and B-995 on growth and endogenous gibberellin content of Cupressus arizonica seedlings. Physiol. Plant. 34:288-292.

Landis, T.D., R.W. Tinus, S.E. McDonald, and J.P. Barnett. 1992. The container tree nursery manual: Atmospheric environment. U.S. Dept. Agr. For. Serv., Washington, D.C.

Larson, R.A. 1992. History, p. 8-11. In: H.K. Tayama, R.A. Larson, P.A. Hammer, and T.J. Roll. Tips on the use of chemical growth regulators on floriculture crops. Ohio Florists' Assn., Columbus.
Little, C.H.A. 1985. Increasing lateral shoot production in balsam fir Christmas trees with cytokinin application. HortScience 20(4):713-714.

Morgan, P.W. and H.W. Gausman. 1966. Effects of ethylene on auxin transport. Plant Physiol. $41: 45-52$.

Neumann, P.M. (ed.). 1988. Plant growth and leaf-applied chemicals. CRC Press, Boca Raton, Fla.

Niu, G., R. Heins, and W. Carlson. 2002. Using paclobutrazol to control height of poinsettia 'freedom'. HortTechnology 12(2):232-236.

Rademacher, W. 1991. Biochemical effects of plant growth retardants, p. 169-200. In: H.W. Gausman (ed.). Plant biochemical regulators. Marcel Dekker, New York.

Ruddat, M. and R.P. Pharis. 1966. Participation of gibberellin in the control of apical dominance in soybean and redwood. Planta 71:222-228.

Ruter, J.M. 1994. Growth and landscape establishment of Pyracantha and Juniperus after application of paclobutrazol. HortScience 29(11):1318-1320.

Schott, P.E. and H. Walter. 1991. Bioregulators: Present and future fields of application, p. 247321. In: H.W. Gausman (ed.). Plant biochemical regulators. Marcel Dekker, New York.

Takeno, K., R.L. Legge, and R.P. Pharis 1981. Effect of the growth retardant B-9 (SADH) on endogenous GA level, and transport and conversion of exogenously applied $\{3 \mathrm{H}\} \mathrm{GA}_{20}$ in alaska pea. Plant Physiol. 67(suppl.):103.

Van den Driessche, R. 1989. Paclobutrazol and triadimefon effects on conifer seedling growth and water relations. Can. J. For. Res. 20:722-729.

Van den Driessche, R. 1996. Drought resistance and water use efficiency of conifer seedlings treated with paclobutrazol. New For. 11:65-83.

Wang, G.G., J. Su, and J.R. Wang. 2000. Height growth of planted black spruce seedlings in response to interspecific vegetation competition: a comparison of four competition measures at two measuring positions. Can. J. For. Res. $30: 573-579$.

Warren, S.L. 1990. Growth response of 13 container-grown landscape plants to uniconazole. J. Environ. Hort. 8(3):151-153.

Warren, S.L., F.A. Blazich, and M. Thetford. 1991. Whole-plant response of selected woody landscape species to uniconazole. J. Environ. Hort. 9(3):163-167.

Weston, G.D., L.W. Carlson, and E.C. Wambold. 1980. The effect of growth retardants and inhibitors on container-grown Pinus contorta and Picea glauca. Can. J. For. Res. 10:510-516.

Wheeler, N.C. 1987. Effect of paclobutrazol on douglas fir and loblolly pine. J. Hort. Sci. 62(1):101-106

Young, E. and J.W. Hanover 1976. Accelerating maturity in Picea seedlings. Acta Hort. 56:105-114. 